\title{
Penerapan Penuntun Praktikum Dengan Menggunakan Metode Discovery Learning untuk Meningkatkan Hasil Belajar Siswa pada Materi Larutan Elektrolit dan Nonelektrolit
}

\author{
Istiani Nanangkong* ${ }^{* a}$, Rymond Rumampuk ${ }^{a}$, Djefry Tani ${ }^{b}$ \\ ${ }^{a}$ Kimia, FMIPA, Universitas Negeri Manado, Minahasa, 95618, Indonesia
}

\section{INFO ARTIKEL \\ Diterima November 2019 \\ Disetujui Desember 2019

\begin{tabular}{l}
\hline Key word: \\
Learning outcomes, discovery \\
learning, experiment, electrolit \\
and nonelectrolit solution \\
\\
\hline Kata kunci: \\
Hasil belajar, discovery \\
learning, praktikum, larutan \\
elektrolit, dan non elektrolit
\end{tabular}

${ }^{*} e$-mail:

istianinanangkong@gmail.com

${ }^{*}$ Telp: 081241457167

\begin{abstract}
A B STRACT
The problem in chemistry learning is that there are various students' understanding of a material, students lack understanding of the chemical concepts being taught. The purpose of this study is to look at student learning outcomes and apply practicum guides using discovery learning methods. The instrument used in this study was the validation sheet of the practical guide. Data collection techniques using interviews, observation and questionnaires. The results of the validation of several experts consisting of three validators show that the practicum guide is in the valid category with a presentation of $86.84 \%$. Based on the results of the study it can be concluded that the learning outcomes of students who use the practicum guide using the discovery learning method succeeded in achieving the KKM value, and $70 \%$ of students exceeded the KKM value set at school.
\end{abstract}

\section{Pendahuluan}

Beragam pemahaman siswa tentang larutan elektrolit dan non elektrolit. Sebagian pemahaman siswa mungkin tepat tetapi sebagian tidak tepat, sehingga dibutuhkan model pembelajaran yang mengunakan praktkum atau model percobaan. Hal ini membantu siswa dalam mengingat karena apa yang di lakukan lebih mudah diingat daripada sesuatu yang dihafalkan. Oleh karena itu praktikum dibutuhkan dalam pembelajaran untuk menarik minat siswa dalam beajar. laboratorium sangat memiliki peranan yang penting dalam pembelajaran sains, apalagi dengan anggapan bahwa kimia itu suatu ilmu yang abstrak, sehingga guru disarankan untuk menggunakan atau menerapkan praktikum dalam proses pembelajaran karena banyaknya manfaat yang diperoleh siswa melalui praktikum seperti konsep-konsep yang dulunya abstrak menjadi menjadi kongkrit [1]. Ada berbagai kendala dalam penerapan praktikum di sekolah, termasuk tidak tersedianya penuntun 
praktikum, sehingga praktikum tidak berjalan secara maksimal, tidak ada panduan penilaian yang dibuat oleh guru, selain itu juga harga bahan dan alat yang digunakan dalam praktikum sangat mahal .

Metode discovery merupakan metode yang cocok untuk meningkatkan pengetahuan siswa karna siswa dapat menemukan pengetahuan sendiri. Metode ini juga dapat meningkatkan kepercayaan siswa terhadap suatu konsep berdasarkan penemuannya dibandingkan dengan apa yang didengarnya. siswa dilibatkan dalam memecahkan masalah, belajar mandiri, berpikir ktitis, dan pemahaman serta berpikir kritis[2]. Model pembelajaran discovery Learning dapat meningkatkan aktivitas dan prestasi siswa[3].

Berdasarkan observasi berupa wawancara dengan guru kimia SMAN 1 Tondano bahwa metode discovery learning belum digunakan dalam praktikum. Karena itu peneliti ingin menerapkan penuntun praktikum dengan menggunakan metode discovery learning bertujuan untuk meningkatakn hasil belajar siswa dan pada penelitian ini menggunakan bahan-bahan yang ada disekitar dalam praktikum larutan elektrolit dan non elektrolit, sehingga praktikum tidak terhalang oleh kendala tidak ada bahan kimia yang tersedia dan mudah dilakukan oleh siswa.

Hasil belajar siswa di SMAN 1 Tondano sudah sebagian besar siswa memenuhi KKM tetapi sebagian masih dibawah rata-rata sehingga dibutuhkan praktikum untuk membantu siswa dalam peningkatan hasil belajarnya.

\section{Metode}

Jenis penelitian yang digunakan dalam penelitian ini adalah penelitian kuantitatif dengan metode penelitian discovery learning. Rancangan penelitian yang digunakan adalah One-Shot Case Study.

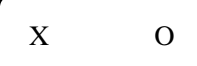

Ket:

$\mathrm{X}=$ perlakuan yang diberikan

$0=$ tes akhir (post test)
Populasi dalam penelitian ini adalah siswa SMA Negeri 1 Tondano. Sampel yang digunakan dalam penelitian ini adalah siswa kelas X IPA 3 SMA Negeri 1 Tondano.

Instrument yang digunakan dalam penelitian ini adalah lembar validasi penuntun praktikum. Ini digunakan agar dapat memperoleh data dari beberapa ahli (validator) tentang penuntun praktikum, sehingga dapat menjadi acuan dalam memperbaiki penuntun praktikum yang telah disusun. Lembar validasi akan di validasi tim ahli terdiri dari 2 dosen Jurusan Kimia Universitas Negeri Manado dan 1 guru Kimia SMA Negeri 1 Tondano.

Dalam penelitian ini mengunakan 3 metode pengumpulan data yaitu metode wawancara, metode observasi dan metode angket.

Teknik analisis data yang dilakukan adalah analisis kevalidan penuntun dan analisis ketuntasan belajar.

Pada teknik ini data diperoleh dari skor pada setiap angket yang telah divalidasi oleh tim ahli. Selanjutnya dikonversi kedalam bentuk presentase untuk mengetahui kevalidannya dengan menggunakan rumus :

$$
P=\frac{\sum X}{\sum X i} \times 100 \%
$$

Untuk menentukan tingkat kevalidan mengacu pada Tabel 1 .

Tabel 1. Skala nilai dan kevalidannya

\begin{tabular}{cc}
\hline Skala nilai (100\%) & Keterangan \\
\hline $81-100$ & Sangat valid \\
$61-80$ & Valid \\
$41-60$ & Cukup valid \\
$21-40$ & Kurang valid \\
$0-20$ & Sangat tidak valid \\
\hline
\end{tabular}

Pada hasil belajar siswa nilai yang diperoleh digunakan untuk menentukan ketuntasan belajar siswa dengan mengacu pada Tabel 2.

Tabel 2. Nilai ketuntasan

\begin{tabular}{ccc}
\hline Nilai & Kategori & Keterangan \\
\hline $\mathbf{1 0 0}$ & $\begin{array}{c}\text { Istimewa/ } \\
\text { maksimal }\end{array}$ & Tuntas \\
\hline $\mathbf{7 5 - 9 9}$ & $\begin{array}{c}\text { Baik sekali/ } \\
\text { optimal }\end{array}$ & Tuntas \\
\hline $\mathbf{6 0 - 7 0}$ & Baik/ & Tidak Tuntas \\
\hline
\end{tabular}




\begin{tabular}{lcc}
\hline & minimal & \\
\hline $\mathbf{5 9 - 4 0}$ & Kurang & Tidak Tuntas \\
\hline
\end{tabular}

\section{Hasil dan Pembahasan}

Berdasarkan hasil penelitian yang dilakukan di SMA Negeri 1 Tondano diperoleh hasil belajar (posttest) menunjukan bahwa nilai rata-rata pada kelas X IPA 3 yang mengunakan metode pembelajaran discovery learning mencapai dan melampaui KKM ( kriteria ketuntasan minimal) yang ditetapkan di sekolah.

Perolehan hasil belajar siswa dinilai melalui empat tahap yaitu tahap persiapan, tahap proses, tahap penutup dan laporan.

1. Tahap persiapan

Aspek yang dinilai adalah kedisiplinan yang terdiri dari hadir tepat waktu, membuat buku jurnal, memperhatikan aturan laboratorium dan menyediakan alat dan bahan.

2. Tahap proses

Pada tahap ini yang dinilai adalah penyiapan larutan stok sampel (larutan garam, larutan gula, larutan detergen dan larutan jeruk nipis) dan pengujian sampel.

3. Tahap penutup

Pada tahap ini item yang dinilai adalah kebersihan dan tanggung jawab, rapid an jujur dalam pengumpulan data hasil pengamatan.

4. Laporan

Penilaian terakhir yaitu pembuatan laporan. Item yang dinilai adalah pembuatan laporan sesuai format, memasukan laporan tepat waktu, menganalisis data praktikum disertai penjelasan, dan terakhir membuat kesimpulan yang sesuai dengan praktikum.

Pengelolahan nilai menggunakan rumus :

$$
N=\frac{\sum S P}{\sum S M} \times 100 \%
$$

Hasil yang diperoleh dari seluruh siswa (30 orang) dinyatakan $100 \%$ lulus dengan nilai mencapai dan melampau KKM ( Kriteria Ketuntasan Minimal). Masing-masing mendapatkan nilai sebanyak 9 orang siswa mendapatkan nilai 75,13 orang mendapatkan nilai 80,4 orang siswa mendapat nilai 85,2 orang mendapat nilai 90, 1 orang mendapatkan nilai 95 dan 1 orang mendapatkan nilai 98 .

Selanjutnya adalah hasil pengolahan data presentase kevalidan penuntun praktikum materi larutan elektrolit dan nonelektrolit diperoleh skor rata-rata 3,47 kemudian dikonversikan menggunakan rumus:

$$
P=\frac{\sum X}{\sum X i} \times 100 \%
$$

Sehingga diperoleh hasil presentase sebesar $86,84 \%$ dengan kategori valid. Dari hasil valiasi dari tim ahli hasil yang diperoleh sangat baik dan layak.

Tabel 3. Data angket validator 1 ahli media

\begin{tabular}{cc}
\hline No Item & Skor Peritem \\
\hline 1 & 4 \\
2 & 4 \\
3 & 3 \\
4 & 3 \\
5 & 3 \\
6 & 4 \\
7 & 4 \\
Jumlah & 25 \\
Presentase & $89,2 \%$ \\
Kategori & Sangat Baik \\
\hline
\end{tabular}

Tabel 4. Data angket validator 2 ahli bahasa

\begin{tabular}{cc}
\hline No Item & Skor Peritem \\
\hline 1 & 3 \\
2 & 4 \\
3 & 3 \\
4 & 3 \\
5 & 4 \\
Jumlah & 17 \\
Presentase & $85 \%$ \\
Kategori & Sangat Baik \\
\hline
\end{tabular}

Tabel 5. Data angket validator 3 ahli materi

\begin{tabular}{cc}
\hline No Item & Skor Peritem \\
\hline 1 & 3 \\
2 & 4 \\
3 & 4 \\
4 & 3 \\
5 & 3 \\
6 & 4 \\
7 & 3 \\
Jumlah & 24 \\
Presentase & $85,7 \%$ \\
Kategori & Sangat baik \\
\hline
\end{tabular}


Penyusunan penuntun praktikum pada penelitian ini menggunakan desain mode pembelajaran ADDIE (Analisia, Desing, Development, Implementation, Evaluation). Langka-langka dari model ADDIE adalah [4]:

1. Analysis (Analisa)

Tahap analisis adalah proses menganalisis beberapa hal seperti kurikulum yang digunakan disekolah, melakukan observasi disekolah melalui wawancara dengan guru mengenai materi yang akan diambil, menganalisis kemampuan siswa dari analisis diatas penulis dapat menulis tujuan praktikum yang akan dilaksanakan, yaitu: siswa dapat mengetahui daya hantar listrik pada berbagai larutan materi larutan elektrilit dan non elektrolit.

2. Design (Desain/ perancangan)

Tahap desain adalah tahap dimana peneliti menyusun desain/ perancangan sesuai dengan tujuan praktikum.

3. Development (Pengembangan)

Tahap pengembangan adalah tahap pengembangan penuntun melalui beberapa ahli yang terdiri dari panelis median, panelis bahasa, dan panelis materi. Penuntun praktikum dirubah berdasarka saran yang diberikan dan penilaian dari tim ahli. Berdasarkan penilaian dari tim ahli diperoleh hasil presentase $86,84 \%$ yang dinyatakan valid. Penilaian dari tim ahli diberikan belalui angket validator.

4. Implementation (Implementasi)

Pada tahap ini penuntun praktikun sudah dinyatakan valid dan siap untuk diterapkan kepada siswa kelas X IPA 3 SMAN 1 Tondano untuk melihat hasil belajar.

5. Evaluation (Evaluasi)

Tahap ini adalah tahap terakhir dari model pembelajran ADDIE. Tahap evaluasi bertujuan untuk melihat sikap siswa terhadap kegiatan pembelajaran dan peningkatan hasil belajar siswa.

\section{Kesimpulan}

Berdasarkan penelitian, maka dapat disimpulkan bahwa Presentase kelayakan penutun praktikum larutan elektrolit dan non elektrolit mencapai $86,84 \%$ yang dikategorikan valid. Untuk seluruh siswa kelas X IPA 3 SMA
Negeri 1 Tondano berhasil mencapai nilai KKM, dan 70\% siswa melampaui nilai KKM ( Kriteria Ketuntasan Minimal) yang ditetapkan.

\section{Daftar Pustaka}

1. Mukhtar, Z., Emiliya. R., Silaban, R. Pengembangan Penuntun Praktikum Model Discovery dan Project Based Learning Pada Pembelajaran Asam Dan Basa Di SMA Kelas XI. JTPPSU. 2015. Vol.12 No. 3

2. Prasetyana, D.S., Sadijan.,Maridi. Pengembangan Model Pembelajaran Discovery Learning Yang Diintegraskan Dengan Group Investigation Pada Materi Protista Kelas X SMA Negeri Karangpandang. JI. (2015), Vol. 4 No. 2

3. Irmi,. Penerapan Model Discovery Learning Melalui Game Gets Lucky Pada Materi Hidrokarbon Dan Minyak Bumi Dalam Peningkatan Aktifitas Dan Hasi Belajar Siswa Kelas X MIPA 2. JIPI. 2018, Vol. 02, No. 01

4. Irmi, N. M., Adlim., Rahmayani, R. F. I. Pengembangan Penuntun Praktikum Kimia Dasar II Berbasis Inkuiri Terbimbing Pada Materi Reaksi Redoks Dan Elektrokimia. JIMPK. 2017, Vol. 2, No. 1 